\title{
BATAS BATAS TANGGUNG JAWAB HUKUM PEJABAT PEMBUAT KOMITMEN TERHADAP KERUGIAN NEGARA DALAM PENGADAAN BARANG / JASA OLEH PEMERINTAH PRINSIP ASAS MASLAHAT
}

\author{
Radian Yudha Pradipta \\ Program Studi Magister Kenotariatan \\ Pasca Sarjana Fakultas Hukum, Universitas Brawijaya \\ Email: radianspradipta@gmail.com
}

Abstract

Procurement involves huge State money. PPK is a party who has authority in carrying out the procurement of goods. Should there be any irregularities that cause material losses to the State's finances to be the responsibility of PPK. Article 11 of Perpres No. 4 of 2015 concerning Procurement of Goods / Services The Government in selecting $P P K$ must meet the requirements of either integrity, managerial or competence. This research is a normative research with literature study. The result of this study is that although the limits of the PPK's legal liability to State Losses in Procurement of Government Goods / Services are not explicitly regulated in Presidential Decree No.4 of 2015 on Procurement of Government Goods / Services, but from several articles, especially in Article 11, Article 12, Article 13 and Article 122 regulating PPK in the event of a State Loss in Procurement of Government Goods / Services. In the event that $P P K$ committed unlawful conduct in its exercise of authority, the CO shall assume responsibility in accordance with the legal liability of PPK for the State Loss from the legal aspects of State administration, civil law and criminal law.

Pengadaan barang melibatkan uang Negara yang sangat besar. PPK adalah pibak yang mempunyai wewenang dalam melaksanakan pengadaan barang. Apabila ada penyimpangan yang menyebabkan kerugian materiil bagi keuangan Negara menjadi tanggung jawab PPK. Pasal 11 Perpres No.4 Tahun 2015 Tentang Pengadaan Barang/Jasa Pemerintah dalam memilih PPK harus memenubi syarat baik integritas, manajerial ataukompetensi. Penelitian ini merupakan penelitian normative dengan 
studi kepustakaan. Hasil dari penelitian ini adalah bahwa walaupun batas-batas tanggungjawab hukum PPK Terhadap Kerugian Negara dalam Pengadaan Barang/ Jasa Pemerintah tidak diatur secara explisit dalam Perpres No.4 Tabun 2015 Tentang Pengadaan Barang/Jasa Pemerintah, akan tetapi dari beberapa pasalnya terutama pada Pasal 11, Pasal 12, Pasal 13, dan Pasal 122 yang mengatur PPK bila terjadi Kerugian Negara dalam Pengadaan Barang/Jasa Pemerintah. Apabila PPK melakukan perbuatan melawan hukum dalam melaksanakan wewenangnya, PPK harus memikul tanggungjawab sesuai dengan bentuk tanggungjawab hukum PPK terhadap Kerugian Negarabaik dari aspek hukum administrasi Negara, bukum perdata dan hukum pidana.

Keywords: Legal Protection, Procurement of Goods and Services, Maslahat

\section{Pendahuluan}

Negara adalah organisasi kekuasaan dari sekelompok manusia yang berkediaman di wilayah tertentu. ${ }^{1}$ Di dalam Pembukaan UUD 1945 tersirat suatu makna, bahwa Negara Republik Indonesia yang berdiri pada tanggal 17 Agustus 1945 adalah negara yang berdasar atas hukum (Rechtsstaat) dalam arti negara pengurus (Verzogingsstaat). ${ }^{2}$ Hal ini tertulis dalm Pembukaan UUD 1945 Alinea ke 4 yang berbunyi sebagai berikut :

“... Untuk membentuk suatu pemerintah negara Indonesia yang melindungi segenap bangsa Indonesia dan seluruh tumpah darah Indonesia dan memajukan kesejahteraan umum, mencerdaskan kebidupan bangsa, dan ikut serta melaksanakan abadi dan keadilan sosial...."3

UUD 1945 menegaskan tentang bentuk dari Negara Indonesia, tentang dalam Pasal 1 Undang-Undang Dasar Negara Republik Indonesia 1945 yang berbunyi "Negara ialah Negara kesatuan, yang berbentuk Republik". Penegasan lebih lanjut negara Indonesia dalam Undang-Undang Dasar Tahun 1945, yaitu Negara Indonesia adalah negara hukum. ${ }^{4}$

Pengadaan Barang / Jasa oleh pemerintah melibatkan uang yang sangat besar. Itulah sebabnya dikatakan pemerintah merupakan pembeli yang terbesar (the largest buyer) di suatu negara. Dalam kaitan ini pemerintah mempunyai tanggung jawab agar kebijakan dalam bidang pengadaan mampu mendukung. Pejabat Pembuat Komitmen atau sering disingkat menjadi PPK, merupakan salah satu pihak dalam pengadaan barang / jasa pemerintah yang peranannya sangat

1 Aim Abdukarim, Pendidikan Kewarganegaraan (Bandung: Grafindo Media Pratama, 2005), h. 15.

2 Maria Farida Indrati S, Ilmu Perundang-Undangan (Jenis, Fungsi, Mater, Muatan) (Jakarta: Kanisius, 2001), h. 1.

3 Pembukaan Alenia 4 Undang-Undang Dasar Negara Republik Indonesia Tahun 1945.

4 Pasal 1 ayat 3 Undang-Undang Dasar Negara Republik Indonesia Tahun 1945. 
penting dalam kesuksesan pelaksanaan pengadaan barang jasa. Tugas utama PPK adalah dalam pelaksanaan kontrak dengan penyedia barang/ jasa yang dipilih oleh Unit Layanan Pengadaan (ULP), dan selain itu ada sedikit tugas dalam proses perencanaan pengadaan yaitu membuat HPS, Spesifikasi Teknis dan membuat draft kontrak. Pejabat Pembuat Komitmen (PPK) dan Panitia Pengadaan adalah pejabat yang diangkat oleh Pengguna Anggaran (PA)/ Kuasa Pengguna Anggaran/ Dewan Gubernur Bank Indonesia (BI) /Pemimpin Badan Hukum Milik Negara (BHMN)/Badan Usaha Milik Daerah (BUMD)/Badan Usaha Milik Negara (BUMN) sebagai pemilik pekerjaan yang bertanggung jawab atas pelaksanaan pengadaan barang dan jasa. ${ }^{5}$ Panitia/Pejabat Penerima Hasil Pekerjaan adalah tim yang diangkat oleh Pengguna Anggaran /Kuasa Pengguna Anggaran/Dewan Gubernur BI/Pempinan BHMN/ Direksi BUMN/ Direksi BUMD, untuk memeriksa dan menerima hasil pekerjaan pengadaan barang dan jasa.

Jika ditinjau dari segi pertanggungjawaban, dalam praktiknya pertanggungjawaban atas penyimpangan terhadap suatu proses pengadaan barang dan jasa Pemerintah dilimpahkan kepada para pejabat dalam struktur pengadaan barang/ jasa khususnya terhadap Pejabat Pembuatan Komitmen (PKK). Hal ini tidak terlepas dari kedudukan dan jabatan Pejabat Pembuat Komitmen (PPK) dalam struktur pengadaan barang dan jasa di Pemerintah yang memiliki tugas, fungsi dan kewenangan dan tanggungjawab yang sangat besar. Pengguna barang/ jasa bertanggungjawab dari segi administrasi, fisik, keuangan dan fungsional atas pengadaan barang/ jasa yang dilaksanakannya. ${ }^{6}$

Kemajuan suatu negara sangat ditentukan oleh kemampuan dan keberhasilannya dalam melaksanakan pembangunan. Pembangunan sebagai suatu proses perubahan yang direncanakan mencakup semua aspek kehidupan masyarakat. Efektifitas dan keberhasilan pembangunan terutama ditentukan oleh dua faktor, yaitu sumber daya manusia, yakni (orang-orang yang terlibat sejak dari perencanaan sampai pada pelaksanaan) dan pembiayaan. Diantara dua faktor tersebut yang paling dominan adalah faktor manusianya. Indonesia merupakan salah satu negara terkaya di Asia dilihat dari keanekaragaman kekayaan sumber daya alamnya.

Kosupsi telah mengakibatkan kerugian materil keuangan negara yang sangat besar. Namun yang lebih memprihatinkan lagi adalah terjadinya perampasan dan pengurasan keuangan negara yang dilakukan secara kolektif oleh kalangan angota legislatif dengan dalih studi banding, THR, uang pesangon dan lain sebagainya

5 Indonesia (A), Peraturan Presiden Tentang Pengadaan Barang / Jasa Pemerintah, Perpres No. 70 Tahun 2012 Ps. 1 angka 7

6 Indonesia (A), Peraturan Presiden Tentang Pengadaan Barang / Jasa Pemerintah, Perpres No. 70 Tahun 2012, Ps. 9 ayat (5) 
di luar batas kewajaran. Bentuk perampasan dan pengurusan keuangan negara demikian terjadi hampir di seluruh wilayah tanah air. Hal itu merupakan cerminan rendahnya motalitas dan rasa malu, sehingga yang menonjol adalah sikap kerakusan dan aji mumpung.

Penulis mencoba menitikberatkan sisi tanggung jawab Kuasa Pengguna Anggaran (KPA), khususnya dalam hal Pengadaan Barang / Jasa di lingkungan pemerintah. Pasal 11 Peraturan Presiden No. 70 Tahun 2012 sendiri mulai mengisyaratkan perlunya pengelola pengadaan, baik pejabat pembuat komitmen maupun panitia pengadaan dan pejabat pengadaan, harus dipilih dari personil yang memenuhi syarat, baik integritas, manajerial maupun kompetensi.

Persyaratan-persyaratan yang disebutkan dalam Peraturan Presiden No. 70 Tahun 2012 memberi gambaran bahwa para pihak yang terlibat didalamnya memiliki perbudaan fokus persyaratan kompetensi. Kompetensi tersebut mulai dari aspek kepemimpinan, teknis maupun manajerial dan pertanggungjawaban.

\section{Metode Penelitian}

Jenis Penelitian, yaitu penelitian yuridis normative dengan metode penelitian hukum kepustakaan. Pendekatan yang digunakan dalam penelitian ini digunakan untuk membangun argumentasi hukum guna memecahkan masalah-masalah yang menyangkut dengan penelitian tersebut, pendekatan yang digunakan ialah Pendekatan Perundang-undangan (statute approach $)^{7}$ dilakukan dengan menelaah undang-undang dan regulasi yang bersangkut paut dengan isu hukum yang sedang diteliti. Dan pendekatan perundang-undangan dilakukan untuk melihat bagaimana tanggung jawab PPK dalam pengadaan barang/jasa Pemerintah bila terjadi kerugian Negara. Dalam pengumpulan bahan hukum, peneliti menggunakan cara mengumpulkan, mempelajari dan mengkaji bahanbahan hukum seperti peraturan perundang-undangan, dokumen-dokumen berupa sertifikat serta putusan pengadilan yang memiliki relevansi dengan permasalahan yang diteliti tersebut.

\section{Pembahasan}

1. Batas-batas Tanggung Jawab Hukum Pejabat Pembuat Komitmen Terhadap Kerugian Negara Dalam Pengadaan Barang/Jasa Pemerintah.

Peraturan Presiden Nomor 4 Tahun 2015 Tentang Pengadaan Barang/Jasa Pemerintah secara explicit tidak mengatur tentang batas-batas tanggung jawab hukum pejabat pembuat komitmen terhadap kerugian Negara dalam pengadaan

7 Peter Mahmud Marzuki, Penelitian Hukum, (Jakarta : Kencana Prenada Media Group, 2005), h. 9394. 
barang/jasa pemerintah. Oleh karena itu pembahasannya didekati dengan melakukan analisis terhadap beberapa pasal yang mengatur tentang wewenang pejabat pembuat komitmen dalam pengadaan barang/jasa pemerintah, mengingat bahwa didalam wewenang akan melekat tanggung jawab hukum.

Dalam pasal 11 ayat (1) dan ayat (2) dinyatakan bahwa:

1. PPK memiliki tugas pokok dan kewenangan sebagai berikut :

a) Menetapkan rencana pelaksanaan Pengadaan Barang/Jasa yang meliputi :

1) Spesifikasi teknis Barang/Jasa;

2) Harga Perkiraan Sendiri (HPS); dan

3) Rancangan Kontrak.

b) Menerbitkan Surat Penunjuk Penyedia Barang/Jasa;

c) Menandatangani Kontrak;

d) Melaksanakan Kontrak dengan Penyedia Barang/Jasa;

e) Mengendalikan Pelaksanaan Kontrak;

f) Melaporkan pelaksanaan/penyelesaian Pengadaan Barang/Jasa kepada PA/ $\mathrm{KPA}$;

g) Menyerahkan hasil pekerjaan Pengadaan Barang/Jasa kepada PA/KPA dengan Berita Acara Penyerahan;

h) Melaporkan kemajuan pekerjaan termasuk penyerapan anggaran dan hambatan pelaksanaan pekerjaan kepada PA/KPA setiap triwulan; dan

i) Menyimpan dan menjaga keutuhan seluruh dokumen pelaksanaan Pengadaan Barang/Jasa.

2. Selain tugas pokok dan kewenangan sebagaimana dimaksud pada ayat (1), dalam hal diperlukan, PPK dapat :

a) Mengusulkan kepada PA/KPA :

1) Perubahan paket pekerjaan; dan/atau

2) Perubahan jadwal kegiatan pengadaan;

b) Menetapkan tim pendukung;

c) Menetapkan tim atau tenaga ahli pemberi penjelasan teknis (aanwijzer) untuk membantu pelaksanaan tugas ULP; dan

d) Menetapkan besaran Uang Muka yang akan dibayar kepada Penyedia Barang/ Jasa.

Pasal 12 dan Pasal 13 dapat menjelaskan bahwa :

Pasal 12

1) PPK merupakan Pejabat yang ditetapkan oleh PA/KPA untuk melaksanakan Pengadaan Barang/Jasa.

2) Untuk ditetapkan sebagai PPK harus memenuhi persyratan sebagai barikut : 
a. Memiliki integritas;

b. Memiliki disiplin tinggi;

c. Memiliki tanggung jawab dan kualifikasiteknis serta manajerial untuk melaksanakan tugas;

d. Mampu mengambil keputusan, bertindak tegas dan memiliki keteladanan dalam sikap perilaku serta tidak terlibat KKN;

e. Menandatangani Pakta Integritas;

f. Tidak menjabat sebagai pengelolah keuangan; dan

g. Memiliki Sertifikat Keahlian Pengadaan Barang/Jasa.

h. Persyaratan manajerial sebagaimana dimaksud pada ayat (2) huruf c adalah:

1) Berpendidikan paling kurang Sarjana Strata Satu (S1) dengan bidang keahlian yang sedapat mungkin sesuai dengan tuntutan pekerjaan;

2) Memiliki pengalaman paling kurang 2 (dua) tahun terlibat secara aktif dalam kegiatan yang berkaitan dengan Pengadaan Barang/Jasa; dan

3) Memiliki kemampuan kerja secara berkelompok dalam melaksanakan setiap tugas/pekerjaan.

Dari Pasal 13 dapat dijelaskan bahwa:

PPK dilarang mengadakan ikatan perjanjian atau menandatangani Kontrak dengan Penyedia Barang/Jasa apabila belum tersedia anggaran atau tidak cukup tersedia anggaran yang dapat mengakibatkan dilampauina batas anggaran yang tersedia untuk kegiatan yang dibiayai dari APBN/APBD. Sedangkan pasal 122 mengatakan bahwa PPK yang melakukan cidera janji terhadap ketentuan yang termuat dalam Kontrak, dapat diminta gaint rugi dengan ketentuan sebagai berikut :

a) Besarnya gant rugi yang dibayar oleh PPK atas keterlambatan pembayaran adalah sebesar bunga terhadapnilai tagihan ang terlambat dibayar, berdasarkan tungkat suku bunga yang berlaku pada saat itu menurut ketetapan Bank Indonesia; atau

b) Dapat diberikan kompensasi sesuai ketentuan dalam Kontrak.

Akhirnya Pasal 123 mengatakan bila terjadi kecurangan dalam pengumuman pangadaan, sanksi diberikan kepada pejabat pangadaan (tarmasuk PPK) sesuai dengan peraturan perundang-undangan, perpres No 4 Tahun 2015 juga menentukan bahwa pengadaan barang dan jasa wajib menerapkan prinsip-prinsip.

PPK dan Panitia Pengadaan dalam mengeluarkan keputusan, ketentuan, prosedur, dan tindakan lainnya, harus didasarkan pada prinsip-prinsip dasar tersebut di atas. Dengan demikian akan tercipta suasana kondusif bagi tercapainya efisiensi, partisipasi dan persaingan yang sehat dan terbuka antara penyedi jasa 
yang setara dan memenuhi syarat, menjamin rasa keadilan dan kepastian hokum bagi semua pihak, sehingga dapat meningkatkan kepercayaan masyarakat terhadap proses pengadaan barang/jasa, karena hasilnya dapat dipertanggungjawabkan kepada masyarakat, baik dari segi fisik, keuangan dan manfaatnya bagi kelancaran pelaksanaan tugas institusi pemerintah.

Wewenang adalah kekuasaan untuk melakukan sesuatu tindakan hokum public, misalnya wewenang PPK menetapkan penyediabarang dan jasa yang nilai pengadaan sampai dengan 50 (lima puluh) miliar rupiah. Sedangkan hak adalah kekuasaan untuk melakukan suatu tindakan hokum privat.

Apabila keputusan pejabat dalam pengadaan barang dan jasa adalahnyata-nyata tidak berwenang, maka keputusan itu adalah batal demi hokum (van recbtswege nietig). Jadi keputusan itu dianggap tidak pernah ada dan bata sejak semula (ex tunc). Berkenaan dengan tindakan pejabat yang tidak berwenang ada suatu contoh klasik, bahwapada Tahun 1906 di kota Kofeniek (sebuah kota kecil di Jerman) di mana seorang tukang sepatu yang berseragam tentara Jerman memerintahkan 12 (dua belas) prajurit Jerman yang sedang jalan-jalan disekitar gedung kota Praja, untuk menculik Walikota dan pegawai kantor pajak. Tindakan tersebut adalah batal demi hokum karena pejabat yang memerintah adalah tidak berwenang. Ketidakwenangan (onbevoegddied) itu ada 3 (tiga) macam :

1. Onbevoegdbeid ratione materiae, artinya pejabat tu pada hakekatnya tidak berwenang untuk melakukan tindakan. Misalnya: PPK menetapkan penyediaan barang dan jasa yang nilai pengadaan di atas lima puluh miliar.

2. Onbevoegdbeid ratione loci, artinya kewenangan pejabat itu dibatasi oleh wilayah tertentu. Misalnya : Panitia Pengadaan Alat Tulis Kantor (ATK) pada Kantor Walikota X memilih penyedia barang dan jasa untuk ATK Universitas Y.

3. Onbevoegdbeid ratione temporis, artinya kewenangan pejabat itu dibatasi oleh waktu tertentu. Misalnya : PPK yang telah berakhir masa jabatannya menandatangani pakta integritas.

Sedangkan Karakter wewenang dapat dibedakan atas :

1. Wewenang terikat adalah wewenang dari pejabat atau bafan pemerintah yang wajib dilaksanakan atau tidak dapat berbuat lain selain dari apa yang tercantum dalam isi sebuah peraturan. Wewenang ini sudah ditentukan isinyasecara rinci, kapan dan dalam keadaan yang bagaimana wewenang tersebut dapat digunakan; dan

2. Wewenang dikreasi (beleidsurijbeid, discretionary power, freies ermessen) adalah wewenang yang diberikan beserta kebebasan dari pejabat untuk mangatur secara lebih konkritdan rinci, sedangkan peraturan perundang-undangan 
hanya memberikan hal-hal yang pokok saja.

Penggunaan wewenang diskresi dalam pengadaan barang dan jasa, misalnya dalam metode pemilihan penyedia barang dan jasa dengan Penunjukan Langsung (PL). Prinsip dasarnya adalah tender, tetapi karena adanya "keadaan tertentu" inilah yang memberikan ruang bagi pejabat untuk menggunakan wewenang diskresi, karena undang-undang tidak merinci secara tegas bagaimana wewenangitu digunakan.

\section{Bentuk-bentuk Tanggung Jawab Hukum Pejabat Pembuat Komitmen \\ Terhadap Kerugian Negara Dalam Pengadaan Barang/Jasa Pemerintah.}

a. Bentuk Tanggung Jawab dari Aspek Hukum Administrasi Negara

Bertolak dari tahapan pengadaan barang dan jasa yang dipaparkan di atas, maka kegiatan pengadaan barang dan jasa yang terkait langsung dengan bidang hukum administrasi adalah kegiatan pada tahap persiapan dan kegiatan pada tahap proses pengadaan, yaitu mulai dari perencanaan pengadaan, pembentukan panitia, penetapan system pengadaan, penyusunan jadwal pengadaan, penyusunan HPS, penyusunan dokumen pengadaan, pemilihan penyedia barang dan jasa. Mengkaji masing-masing kegiatan tersebut harus bertumpu pada kewenangan yang sah (atribusi, delegasi, mandat) dari para pejabat yang terkait dengan pelaksanaan pengadaan barang dan jasa.

\section{b. Perencanaan Pengadaan}

Sebagaimana ditentukan dalam pasal 11 ayat (1) huruf a perpres Nomor 4 Tahun 2015 bahwa salah satu wewenang PPK adalah menyusun perencanaan pengadaan barang dan jasa. Dalam menyusun perencanaan pengadaan barang dan jasa, PPK diwajibkan melakukan pemaketan pekerjaan. Dalam penentuan paket pengadaan, PPK bersama panitia, wajib memaksimalkan penggunaan produksi dalam negeri dan perluasan kesempatan bagi usaha kecil termasuk koperasi kecil. Bakaitan dengan pemaketan pekerjaan, PPK sendiri diwajibkan:

1. Menetapkan sebanyak-banyaknya paket pengadaan untuk usaha kecil termasuk koperasi kecil tanpa mengabaikan prinsip efisiensi, kesatuan system barang dan jasa, kualitas dan kemampuan teknis usaha kecil termasuk koperasi kecil;

2. Mengumumkan secara luas paket-paket pekerjaan dan rencana pelaksanaan pengadaan sebelum proses pemilihan penyedia barang dan jasa dimulai.

Dalam kaitannya dengan pemaketan pekerjaan, PPK dilarang untuk : 
1. Memecah pengadaan barang dan jasa menjadi beberapa paket dengan maksud untuk menghindari pelelangan;

2. Menyatukan atau memusatkan beberapa kegiatan yang tersebar di beberapa daerah yang menurut sifat pekerjaan dan tingkat efisiensinya searusnya dilakukan di daerah masing-masing;

3. Menyatukan/menggabungkan beberapa paket pekerjaan yang menurut sifat pekeraan dan besaran nilainya searusnya dilakukan oleh usaha kecil termasuk koperasi kecil menjadi satu paket pekerjaan untuk dilaksanakan oleh perusahaan/koperasi menengah dan/atau besar;

4. Menentukan criteria, persyaratan atau prosedur pengadaan yang diskriminatif dan/atau dengan pertimbangan yang tidak obyektif.

Mercermati kegiatan yang terkait dengan tahap perencanaan pengadaan di atas, termasuk yang terkait dengan kewajiban dan larangan, maka PPK yang melalaikan kewajiban dan melanggar larangan tersebut dapat dikenakan sanksi administratif.

c. Penetapan Metode Pengadaan

Pengaturan mengenai metode pengadaan barang dan jasa diatur dalam Pasal 11 Perpres No 4 Tahun 2015

1. Dalam pemilihan penyedia barang/jasa pemborong/jasa lainnya, pada prinsipnya dilakukan melalui metode pelelangan umum.

2. Pelelangan umum adalah metode pemilihan penyedia barang/jasa yang dilakukan secara terbuka dengan pengumuman secara luas sekurngkurangnya di satu surat kabar nasional dan/atau satu surat kabar provinsi.

3. Dalam hal jumlah penyedia barang/jasa yang mampu melaksanakan diyakini terbatas dan untuk pekerjaan yang kompleks, maka pemilihan penyedia barang/jasa dapat dilakukan dengan metode pelelangan terbatas dan diumumkan secara luas sekurang-kurangnya di satu surat kabar nasional dan/atau satu surat kabar provinsi dengan mencantumkan penyedia barang/jasa yang mampu, guna member kesempatan kepada penyedia barang/jasa lainnya yang memenuhi kualifikasi.

4. Dalam hal metode pelelangan umum atau pelelangan teratas dinilai tidak efisien dari segi biaya pelelangan, maka pemilihan penyedia barang/jasa dapat dilakukan dengan metode pemilihan langsung, yaitu pemilihan penyedia barang/jasa dilakukan dengan membandingkan sebanyakbanyaknya penawaran, sekurang-kurangnya 3 (tiga) penawaran dari 
penyedia barang/jasa yang telah lulus prakualifikasi serta dlakukan negosiasi baik teknis maupun biaya serta harus diumumkan minimal melalui papan pengumuman resmi untuk penerangan umum dan bila dimungkinkan melalui internet.

5. Dalam keadaan tertentu dan keadaan khusus, pemilihan penyedia barang/jasa dapat dilakukan dengan cara peenunjukan langsung terhadap 1 (satu) penyedia barang/jasa dengan cara melakukan negosiasi baik teknis maupun biaya sehingga diperoleh harga yang wajar dan serta teknis dapat dipertanggungjawabkan.

Berkenaan dengan kewenangan PPK untuk menetapkan dan mengesahkan metode pengadaan barang/jasa yang disusun panitia pengadaan, maka pada prinsipnya PPK melakukan pemilihan penyedia barang dan jasa dengan pelelangan umum. Akan tetapi dalam keadaan tertentu PPK dapat menggunakan kewenangan diskresi-nya untuk menetapkan metode pemilihan penyedia barang dan jasa dengan mempertimbangkan jenis, sifat, dan nilai barang dan jasa serta kondisi lokasi, kepentingan masyarakat dan jumlah penyedia barang dan jasa yang ada.

Jika terjadi kesalahan dalam penetapan metode pengadaan barang dan jasa, maka instrumen hukum untuk menilai kewenagnan diskresi adalah asas-asas umum pemerintahan yang baik.

\section{d. Penyusunan HPS}

Harga Perkiraan Sendiri (HPS) berfungsi sebagai instrumen untuk menilai kewajaran harga penawaran dan untuk menetapkan besaran tambahan nilai jaminan pelaksanaan bagi penawaran yang dinilai terlalu rendah, tetapi tidak dapat dijadikan dasar untuk menggurkan penawaran. Panitia pengadaan bertugas menyusun HPS, sedangkan yang berwenang menetapkan dan mengesahkan HPS adalah PKK. Panitia Pengadaan dalam melakukan perhitungan HPS harus dilakukan dengan cermat, dengan menggunakan data dasar dan mempertimbangkan:

1. Analisi harga satuan pekerjaan yang bersangkutan;

2. Perkiraan perhitungan biaya oleh konsultan/engineer's estimate (EE)

3. Harga pasar setempat pada waktu penyusunan HPS;

4. Harga kontrak/Srat Pemerintah Kerja (SPK) untuk barang dan pekerjaan sejenis setempat yang pernah dilaksanakan;

5. Informasi harga satuan yang dipublikasikan secara resmi oleh Badan Pusat Statistik (BPS), badan/instansi lainnya dan media cetak yang datanya dapat dipertanggungjawabkan;

6. Harga/tarifbarang dan jasa yang dikeluarkan oleh pabrikan/agen tunggal 
atau lembaga independen;

7. Daftar harga standar/tarif biaya yang dikeluarkan oleh instansi yang berwenang;

8. Informasi lain yang dapat dipertanggungjawabkan

HPS tidak memperhitungkan biaya tak terduka, biaya lain-lain dan Pajak Penghasilan $(\mathrm{PPh})$ penyedia barang dan jasa. Sebagaimana telah diutarakan di atas, bahwa PPK berwenang menetapkan dan mengesahkan HPS yang telah disusun oleh panitia pengadaan. Aspek hukum administrasi dari penetapan HPS ini, oleh karena penetapan HPS tersebut merupakan keputusan pejabat tata usaha Negara, sehingga jika terjadi kesalahan dalam penetapan tersebut, maka dapat digugat di Pengadilan Tata Usaha Negara (PTUN) untuk dimintakan pembatalannya

Berdasarkan ketentuan pasal 35 Perpres 4 Tahun 2015 menetapkan dan mengesahkan hasil pengadaan panitia pengadaan sesuai kewenangannya. Frasa "sesuai kewenangannya" berarti bahwa tidak semua hasil pemilihan penyedia barang dan jasa yang dilakukan oleh panitia pengadaan menjadi kewenangan PPK untuk menetapkan dan mengesahkannya, apabila nilai pengadaan itu sampai dengan Rp. 50.000.000.000,00 (lima puluh miliar Rupiah), jika nilai pengadaanya lebih dari Rp. 50.000.000.000,00 (lima puluh miliar rupiah) mennjadi kewenangan menteri.

Dalam konsep hukum administrasi, penetapan penyedia barang dan jasa termasuk keputusan pejabat tata usaha negara. Oleh sebab itu, apabila keputusan itu merugikan pihak-pihak yang berkepentingan maka pihak tersebut dapat menggugat ke Pengadilan Tata Usaha Negara. Sehingga tahap penetapan penyedia barang dan jasa termasuk dalam bidang kajian hukum administrasi, kecuali dalam proses penetapan tersebut terbukti ada unsur maladministrasi

e. Bentuk Tanggungjawab dari Apek Hukum dalam Pengadaan Barang dan Jasa

Salah satu tugas PPK menurut Pasal Perpres Nomor 4 Tahun 2015 adalah menyiapkan kontrak. Terkait dengan tugas ini, maka PPK dalam menyusun kontrak harus memperhatikan hal-hal yang harus dumuat dalam Kontrak Pengadaan Barang dan Jasa (KPBJ). Menurut ketentuan, kontrak sekurang-kurangnya memuat ketentuan sebagai berikut:

1. Para pihak yang menandatangani kontrak yang meliputi nama, jabatan, dan alamt;

2. Pokok pekerjaan yang diperjanjikan dengan uraian yang jelas mengenai jenis dan jumlah barang/jasa yang diperjanjikan;

3. Hak dan kewajiban para pihak yang terikat di dalam perjanjian; 
4. Nilai atau harga kontrak pekerjaan, serta syarat-syarat pembayaran;

5. Persyaratan dan spesifikasi teknis yang jelas dan terinci;

6. Tempat dan jangka waktu penyelesaian/penyerahan dengan disertai jadual waktu penyelesaian/penyerahan yang pasti serta syarat-syarat penyerahannya;

7. Jaminan teknis/hasil pekerjaan yang dilaksanakan dan/atau ketentuan mengenai kelaikan;

8. Ketentuan mengenai cidera janji dan sanksi dalam hal para pihak tidak memenuhi kewajibannya;

9. Ketentuan mengenai pemutusan kontrak secara sepihak;

10. Ketentuan mengenai keadaan memaksa;

11. Ketentuan mengenai kewajiban para pihak dalam hal terjadi kegagalan dalam pelaksanaan pekerjaan;

12. Ketentuan mengenai pelindungan tenaga kerja;

13. Ketentuan mengenai bentuk dan tanggung jawab gangguan lingkungan;

14. Ketentuan mengenai penyelesaian perselisihan.

15. Aspek Maslahat

Maslahah berasal dari kata salaha yang secara arti kata berarti baik lawan dari kata buruk atau rusak. Maslahah adalah kata masdar salah yang artinya yaitu manfaat atau terlepas daripada kerusakan. Maslahah dalam bahasa arab adalah perbuatan-perbuatan yang mendorong kepada kebaikan manusia. Secara esensi maslahah merupakan suatu kemaslahatan yang tidak mempunyai dasar dalil, tetapi juga tidak ada pembatalannya jika terdapat suatu kejadian yang tidak ada pembatalannya jika terdapat suatu kejadian yang tidak ada ketentuan syariat dan tidak ada 'illat yang keluar dari syara; yang menentukan kejelasan hukum tersebut, kemudian ditemukan suatu yang sesuai dengan hukum syara, yaitu suatu ketentuan yang berdasarkan pemeliharaan kemudharatan atau untuk menyatakan suatu manfaat, maka kejadian tersebut dinamakan maslahah. ${ }^{8}$ Tujuan utama maslahah ialah kemaslahatan, yaitu memelihara kemudharatan dan menjaga manfaatnya.

Dalam permasalahan ini, PPK sebagai pihak yang berwenang dalam Pengadaan Barang/Jasa Pemerintah bekerja untuk memenuhi kebutuhan Negara agar bekerja tidak baik tanpa ada penyelewengan. Hal yang demikian masuk pada kategori maslahah yang dari segi tingkatannya ini berkaitan dengan kepentingan hajat hidup manusia. Menurut Mustafa al-Khind, Maslahah dilihat dari segi martabatnya ini dapat dibedakan menjadi tiga macam, antara lain maslahah

8 Romli, SA, Muqaranah Mazabib Fil Usul (Jakarta:Gaya Media Pratama, 1999), h. 158. 
daruriyah, maslahah hajiyah, dan maslahah tabsiniyah. Maslahah daruriyah merupakan maslahah yang sesuai dengan permasalahan ini. Maslahah daruriyah adalah kemaslahatan yang menjadi dasar tegaknya kehidupan hak asasi manusia, baik yang berkaitan dengan agama maupun dunia. Jika ia luput dalam kehidupan manusia maka mengakibatkan rusaknya tatanan kehidupan manusia. Zakaria alBisri menyebutkan bahwa maslahah daruriyah ini merupakan dasar asasi untuk menjamin kelangsungan hidup manusia, jika ia rusak maka akan muncullah fitnah dan bencana yang besar.

\section{Simpulan}

Dari uraian pada bab-bab terdahulu maka dapat disimpulkan sebagai berikut:

1. Bahwa walaupun batas-batas tanggung jawab hukum Pejabat Pembuat Komitmen Terhadap Kerugian Negara dalam Pengadaan Barang/Jasa Pemerintah tidak diatur secara explisit dalam Perpres No 4 Tahun 2015 Tentang Pengadaan Barang/Jasa Pemerintah, akan tetapi dari beberapa pasalnya terutama pada Pasal 11, Pasal 12, Pasal 13, dan Pasal 122 yang mengatur tentang wewenang PPK, persyaratan bagi PPK, larangan PPK dan sanksi-sanksi yang dapat dikenakan terhadap PPK bila terjadi Kerugian Negara dalam Pengadaan Barang/Jasa Pemerintah. Dan berdasarkan kontrak bahwa dalam wewenang akan selalu melekat pertanggung jawaban, maka apabila PPK melakukan perbuatan welawan hukum dalam melaksanakan wewenangnya, PPK harus memikul tanggung jawab sesuai dengan kesalahannya

2. Bahwa bentuk tanggung jawab hukum PPK terhadap Kerugian Negara dalam Pengadaan Barang/Jasa Pemerintah dapat ditinjau dari aspek hukum administrasi Negara, hukum perdata dan hukum pidana. Hak administasi bisa berupa: denda administrasi, penarikan kembali keputusan TUN yang mengajukan ataupun sanksi kepegawaian. Dari aspek hak perdata bisa berupa ganti rugi atas wanprestasi yang dilakukannya.Dari aspek hak pidana, PPK dapat dituntut secara pidana, terutama bisa terdapat korupsi, kolusi dan nepotisme (KKN), mark up terhadap harga yang telah ditetapkan dalam Pengadaan Barang/Jasa Pemerintah.

3. Maslahab daruriyah menjadi maslahah yang sesuai dengan permasalahan ini karena berkaitan dengan kepentingan hajat hidup manusia. Apabila tidak ditertibkan, maka akan mengakibatkan rusaknya tatanan kehidupan manusia. 
Daftar Pustaka

Buku

Ashofa, Burhan. Metode Penelitian Hukum. Jakarta: Rineka Cipta, 1998.

Badan Pendidikan dan Pelatihan Keuangan. Pelaksanaan Pengadaan Barang dan Jasa Pemerintah. Jakarta: 2007.

Dinas PU Bina Marga. Visi dan Misi. (online) (http://jombangkab.go.id/ diakses 17 April 2017).

Dinas PU Bina Marga. Visi dan Misi. (online) (http://jombangkab.go.id/ diakses 17 April 2017).

HR, Ridwan. Hukum Administrasi Negara. Jakarta: Raja Grafindo, 2008.

Keban, Yeremias T. Enam Dimensi Stategis Administrasi Publik. Yogyakarta: Gava Media, 2008.

Mochtar Kusuma Admadja dan Sidartha Arief. Pengantar Ilmu Hukum Suatu Pengenalan Pertama RuangLingkup Berlakunya Ilmu Hukum Buku I. Bandung: Alumni, 2000.

Pejabat Pembuat Komitmen Dalm Pengadaan Barang dan Jasa Pemerinta. (Online) (http://bdksemarang.kemenag.go.id/ diakses 18 April 2017).

Peraturan Menteri Keuangan 190/PMK.05/2012 tentang Tatacara PembayaranDalam Rangka Pelaksanaan Anggaran PendapatanBelanja Negara.

Peraturan Presiden No.70 Tahun 2012 tentang PengadaanBarang/Jasa Pemerintah.

Puriyadi. Siasat Anggaran : Posisi Masyarakat DalamPerumusan Anggaran Daerah. Yogjakarta: Lokus, 2007.

Pusdiklatwas BPKP. Pedoman Pelaksanaan Anggaran II, Diklat Pembentukan Auditor Abli. Edisi VI, 2010.

Sedarmayanti dan Syarifudin Hidayat. Metodologi Penelitian. Bandung: Mandar Mundur, 2002.

Simamora, Yohanes Sogar. Hukum Perjanjian_Prinsip Hukum Kontrak Pengadaan Barang dan Jasa oleh Pemerintah. Yogyakarta: LaksBang Pressindo, 2009. 
Soeharto, Imam. ManajemenProyek (DariKonseptual Sampai Operasional). Jakarta: Erlangga, 2001.

Sunggono, Bambang. Metode Penelitian Hukum. Jakarta: Raja Grafindo Persada, 2003.

Supratman. Metode Penelitian Hukum. Malang: Alvabeta, 2012.

Widjaja. Otonomi Daerahdan Daerah Otonom/ HAW.Jakarta: Raja Grafindo Persada, 2002. 